\title{
Area-based management and fishing efficiency
}

\author{
Paul Marchal ${ }^{\mathrm{a}, *}$, Clara Ulrich ${ }^{\mathrm{a}}$, Martin Pastoors ${ }^{\mathrm{b}}$ \\ ${ }^{a}$ DIFRES, Charlottenlund Slot, DK 2920 Charlottenlund, Denmark \\ ${ }^{\mathrm{b}}$ RIVO-DLO, P.O. Box 68, NL-1970 AB Ijmuiden, Netherlands
}

Received 30 April 2001; accepted 18 December 2001

\begin{abstract}
The scope of this study is to investigate the extent to which area-based management may have influenced the fishing efficiency of the Danish and Dutch demersal fleets harvesting cod, plaice and sole in the North Sea. Special consideration is given to the 'plaice box', a restricted area where fishing is prohibited to towed-gear fleets of horsepower exceeding $300 \mathrm{hp}$. An index of fishing power is calculated as the log-ratio between the catch per unit effort (CPUE) of any vessel and some survey abundance index. Annual trends in fishing are calculated as the year-effect derived from a general linear model (GLM) analysis of the index of fishing power. The fishing efficiency of Danish gill-netters and, to some extent, Danish seiners, has overall increased inside the 'plaice box', whilst remaining relatively stable outside. However, the fishing efficiency of the other exemption fleets has apparently been subject to little change. Overall, it is not possible to determine the extent to which the 'plaice box' has contributed to the fishing efficiency dynamics of the exemption fleets. However, some of the results of this study bear out the conclusions from recent investigations. (C) 2002 Ifremer/CNRS/Inra/IRD/Cemagref/Éditions scientifiques et médicales Elsevier SAS. All rights reserved.
\end{abstract}

\section{Résumé}

Fermeture de zones et efficacité de pêche. L'objectif de cette étude est d'évaluer dans quelle mesure une gestion des pêcheries basée sur la restriction de l'accès à certaines zones de pêche pourrait avoir affecté l'efficacité de pêche des flottilles démersales danoises et hollandaises, qui exploitent la morue, la plie et la sole en mer du Nord. Une considération particulière est accordée à "la boîte à plie", une zone de pêche interdite aux chalutiers dont la puissance motrice excède $300 \mathrm{CV}$. Un indice de puissance de pêche est calculé par le logarithme du quotient entre capture par unité d'effort (CPUE) commerciale et un indice de pêche dérivé de campagnes de recherche en mer. Les tendances annuelles de l'efficacité par pêche sont alors estimées, pour chaque flottille, espèce et zone de gestion, par l'effet "année" dérivé d'une analyse de type GLM (modèle linéaire général) de l'indice de puissance de pêche. L'efficacité de pêche des fileyeurs danois et, dans une certaine mesure, des seineurs danois, a globalement augmenté à l'intérieur de "la boîte à plie", tout en restant relativement stable à l'extérieur. De manière générale, il n'est pas possible de déterminer dans quelle mesure l'application de "la boîte à plie" a contribué à la modification de l'efficacité de pêche des flottilles exemptées. Cependant, certains de ces résultats confirment les résultats d'études récentes. () 2002 Ifremer/CNRS/Inra/Cemagref/Éditions scientifiques et médicales Elsevier SAS. Tous droits réservés.

\section{Introduction}

The link between the fishing activity and the pressure exerted on the fish populations (fishing mortality) is of particular importance in relating fishing intensity to biological sustainability. This link is usually referred to as the

\footnotetext{
* Corresponding author: Ifremer, 150 quai Gambetta, 62321 Boulogne sur mer, France.

E-mail address: pmarchal@ifremer.fr (P. Marchal).
}

catchability coefficient, and it is often represented as the ratio between fishing mortality and some measure of fishing activity Beverton and Holt, 1957). It is not a trivial task to calculate catchability dynamics, because of their inherent complexity Crecco and Overholtz, 1990; Arreguin-Sanched and Pitcher, 1999), and also because of the risk of partially mistaking these dynamics for stock fluctuations Gulland 1964: Atran and Loesch, 1995)

As a result of poor knowledge, catchability dynamics are often kept simple (Paloheimo, 1980; Deriso et al., 1985; 
Mendelssohn and Cury. 1989: Lehodey et al. 1994: Shepherd 1999: ICES. 1999a]. However, over-simplifying the catchability model could lead to corrupted stock assessments CMegrey, 1989; Arreguin-Sanchez. 1996: Chen and Paloheimo.1998) and could also adversely affect fishery management plans based on fishing effort control Holden. 1994: Anonymous: 1999, 2000a).

Identifying and accounting for historical fluctuations in catchability could enhance the quality of stock assessments Megrey_ 1989) and a number of methods have been developed in that respect. Thus, some stock assessment models allow for the direct estimation of annual catchabilities Eournier and Archibald. 1982 or systematic trends in catchability, as in the 'Hybrid method' (Pope and Shepherd. 1985. Alternatively, catchability dynamics could be calculated as the ratio between partial fishing mortality, derived from stock assessment diagnostics, and partial fishing effort, provided fishing mortalities are robust to uncertainties in catchability Cook and Armstrong. 1985: Millischer et al. 1999]. Finally, trends in catchability could be evaluated by the analysis of the ratio between the catch per unit effort (CPUE) of a fleet relative to the CPUE of a set of vessels belonging to this fleet and which have constant fishing power over time (Marchal et al, 2001a).

However, none of the approaches described above allow predicting future catchability trajectories. Such predictions could only be made possible by explicitly building up a catchability model relative to some input parameters. Thus, substantial research has been carried out to investigate the relationship between catchability and stock availability Crecco and Overholtz 1990. Swain et al 1994) gear characteristics Hovgård, 1996), vessel attributes (Rohson 1966, and skipper's and crew's skill Pascoe and Rohinson. 1996. Management regulations (including catch quota, gear restrictions, and season and area closures) are also likely to be a determinant of catchability. Past studies have investigated the impact of various management regimes on fish stocks Pastoors et al_2000) spatial allocation of fishing effort Maury and Gascuel 1999) or the overall productivity of fisheries CClark, 1980: Arnason, 1994. However, the impact of management regulations on catchability dynamics has hardly been examined.

Management regulations may affect catchability dynamics through a number of mechanisms. Thus, recent investigations have demonstrated that modifying the competitive interactions between vessels for given fishing grounds could alter their fishing efficiency Gillis and Peterman 1998. Rijnsdorp et al. 2000) Therefore, the enforcement of any management regulations, such as restricted areas, which would result in a reallocation of the fishing effort on fishing grounds, would also be expected to have an impact on the vessels' efficiency. The scope of this study is to examine the impact of some area-based management regulations on the fishing efficiency of some demersal fisheries in the North Sea. The main area-based technical measures under investigation are the 'plaice box' and the ' 12 nautical mile zone', where fishing is prohibited to towed-gear vessels using a horsepower exceeding $221 \mathrm{~kW}$ (Anonymous, 1997; ICES, 1999b). Some attention will also be paid to the areas situated north and south of latitude $55^{\circ} \mathrm{N}$ in the North Sea, where different mesh size regulations apply CAnonymous. 1997) This study is applied to the Danish and Dutch demersal fisheries harvesting plaice, sole and cod in the North Sea.

\section{Material and methods}

\subsection{Material}

\subsubsection{Management areas}

The North Sea demersal fisheries are regulated by four main area-based technical measures, hereby referred to as the 12 nautical mile zone, the plaice box, the ' $100-\mathrm{mm}$ mesh size area' and the ' $80-\mathrm{mm}$ mesh size derogation area'. These management measures are described extensively in Anonymous_(1997), and they are summarised below.

In the 12 nautical mile zone, extending from the French coast at $51^{\circ} \mathrm{N}$ to Hirtshals in Denmark, the general rule is that trawling is prohibited to vessels exceeding $300 \mathrm{hp}$ or $24 \mathrm{~m}$ overall length. There are a few exempted fleets, particularly the beam-trawlers targeting shrimps.

In addition to the 12 nautical mile zone, the plaice box was established in 1989 , extending from $53^{\circ} \mathrm{N}$ to $57^{\circ} \mathrm{N}$ along the coasts of The Netherlands, Germany and Denmark and about 30 nautical miles wide, where the same restrictions are in force as in the ' 12 mile zone' that is part of it (in effect, no beam-trawling by vessels over $24 \mathrm{~m}$ overall length with engines over $300 \mathrm{hp}$ ). Initially the restriction applied only to the second and third quarter; in 1994 it was extended to the fourth quarter and since 1995 it has been closed during the whole year. The plaice box has been implemented as a means of protecting the nursery areas of plaice, off the coasts of Denmark, Germany, Holland and Belgium.

The minimum mesh size for fishing for demersal species in the North Sea is currently $100 \mathrm{~mm}$. Of the few exemptions to this general rule, one is particularly relevant to the flatfish fishery. Thus, fishing for sole south of $55^{\circ} \mathrm{N}$ is allowed with $80-\mathrm{mm}$ meshes in the cod end, provided that at least $5 \%$ of the catch is sole, and no more than $10 \%$ of the catch is composed of cod, haddock and saithe. Since 1 January 2000, the ' $80-\mathrm{mm}$ mesh size derogation area' has been extended to the area east of $5^{\circ} \mathrm{E}$ and south of $56^{\circ} \mathrm{N}$.

The 12 nautical mile zone and the plaice box do not match exactly the contour of the statistical rectangles set up by the International Council for the Exploration of the Sea (ICES), which represents the smallest geographical unit (30 nautical miles $\times 60$ nautical miles) where catch and effort data are available. These inconsistencies could lead to important errors, because some fisheries have tended to aggregate just outside the restricted areas [ICES, 1999b. As a result, the fishing effort of the fleets fishing close to the 
Lat. $\mathrm{N}$

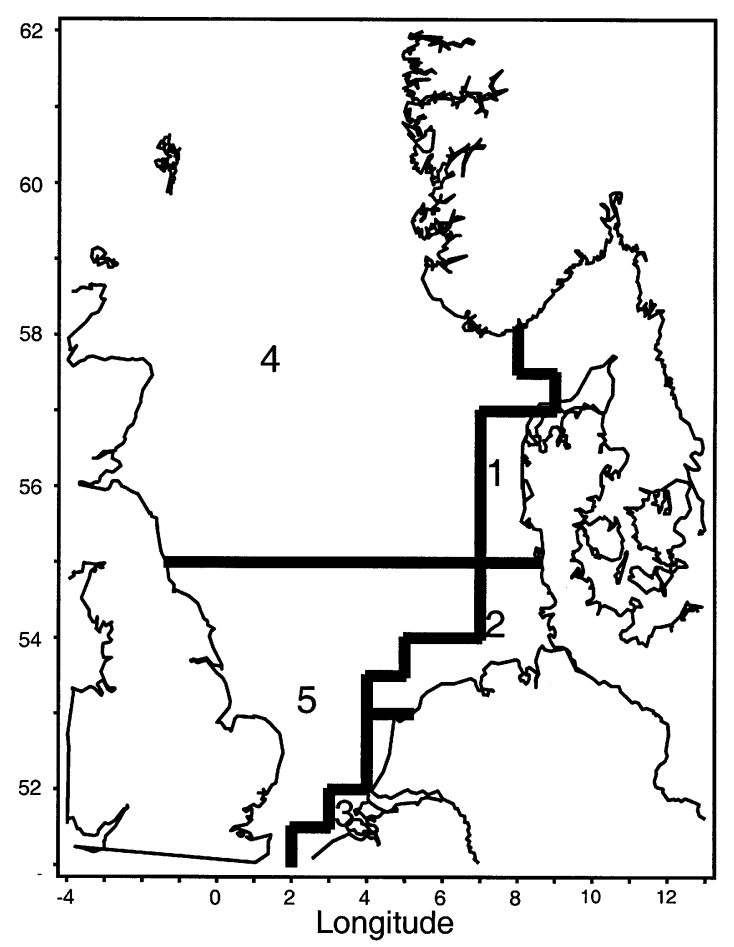

Fig. 1. Approximate limits of some management areas of the North Sea: the 12 nautical mile zone (area 3), the plaice box (areas 1 and 2), the 80-mm mesh size derogation area (areas 2, 3 and 5) and the 100-mm mesh size area (areas 1 and 4).

border of the restricted areas has been adjusted, as explained in the following subsection ('Commercial fisheries'). Finally, the North Sea has been split into five management areas, as defined below and shown in Fig. 1:

- Area 1: Set of ICES rectangles, located entirely or partially in the plaice box, and in the 100-mm mesh size area;

- Area 2: Set of ICES rectangles, located entirely or partially in the plaice box, and in the 80 -mm mesh size derogation area;

- Area 3: Set of ICES rectangles, located entirely or partially in the 12 nautical mile zone off the French, Belgian and Dutch coastline;

- Area 4: Set of ICES rectangles, located entirely outside the plaice box, and in the 100-mm mesh size area; and

- Area 5: Set of ICES rectangles, located entirely outside the plaice box and the 12 nautical mile zone, and in the 80-mm mesh size derogation area.

\subsubsection{Commercial fisheries}

This study is based on the Danish and Dutch demersal fleets harvesting cod, sole and plaice in the North Sea, defined as ICES division IV. Fleets are here defined as a combination of gear and horsepower categories (beamtrawlers, otter-trawlers, Danish seiners), or simply gear (netters). Two horsepower classes, below and above $300 \mathrm{hp}$, have been investigated, consistently with the horsepower categories, to which restrictions apply in the 12 nautical mile zone and in the plaice box. Information on mesh size was considered imprecise, and could not be used for the purpose of this study. The Danish demersal fishery, composed of otter-trawlers (below and above $300 \mathrm{hp}$ ), gill netters (no hp distinction) and Danish seiners (below $300 \mathrm{hp}$ ) targets cod and plaice, while the Dutch demersal fishery, mainly made up of beam-trawlers (below and above $300 \mathrm{hp}$ ), is primarily targeting plaice and sole.

Catch and effort data for these fisheries are extracted from the national logbook databases. Data are regularly available over 1987-1998 (Denmark) and 1991-1998 (The Netherlands). However, information on the spatial distribution of Danish vessels has only been reliable since 1991, with less than $2 \%$ of fishing effort misallocation. As a result, it was not possible to have data prior to the period where the three management measures under investigation came into force. However, data are available prior to 1995, the year in which the plaice box became fully implemented.

Fishing activity for the purpose of the analysis has been expressed as number of days fishing. The spatial distribution of fishing activity has been represented for the Danish (Fig. 2) and Dutch (Fig. 3) fleets under consideration, in 1992, 1994, 1996 and 1998. It can be seen that there is still a substantial amount of trawlers exceeding $300 \mathrm{hp}$ fishing in the 12 nautical mile zone and in the plaice box after its full implementation in 1995 (Figs. 2d, 3b). As discussed in the previous subsection entitled 'Management areas', this apparent contradiction results from the boundaries of the closed areas not matching exactly the ICES rectangles definitions. Consistent with $\operatorname{LCES}(1999 \mathrm{~b})$, the fishing effort of trawlers exceeding $300 \mathrm{hp}$, which were registered in the ICES rectangles including both a zone located inside and outside the restricted areas (e.g., 39F7), was reallocated to the next contiguous rectangle entirely located outside the restricted areas (e.g., 39F6).

It may be anticipated that the overall fishing activity of the different Danish and Dutch fleets has changed over time. However, the geographical allocation of fishing activity has not varied dramatically across the years under examination. The fishing activity of the Danish fleets is concentrated in areas 1, 4 and 5, while the Dutch beam trawlers operate primarily in areas 2, 3,4 and 5. The Danish and Dutch small trawlers operate generally in the neighbourhood of their home coastline (i.e., areas 1, 2 and 3), while the other fleets are more ubiquitous.

\subsubsection{Research surveys}

Stock abundance indices used to perform the present analysis are derived from international (IBTS, International Bottom Trawl Survey, first quarter) and Dutch (DBTS, Dutch Beam Trawl Survey, third quarter) investigations.

The International Bottom Trawl Survey (IBTS) coordinates national surveys carried out by each ICES member country coasting the North Sea, the Kattegat and the Skagerrak. The IBTS was initiated in the early 1970s and 
Lat. $\mathbf{N}$
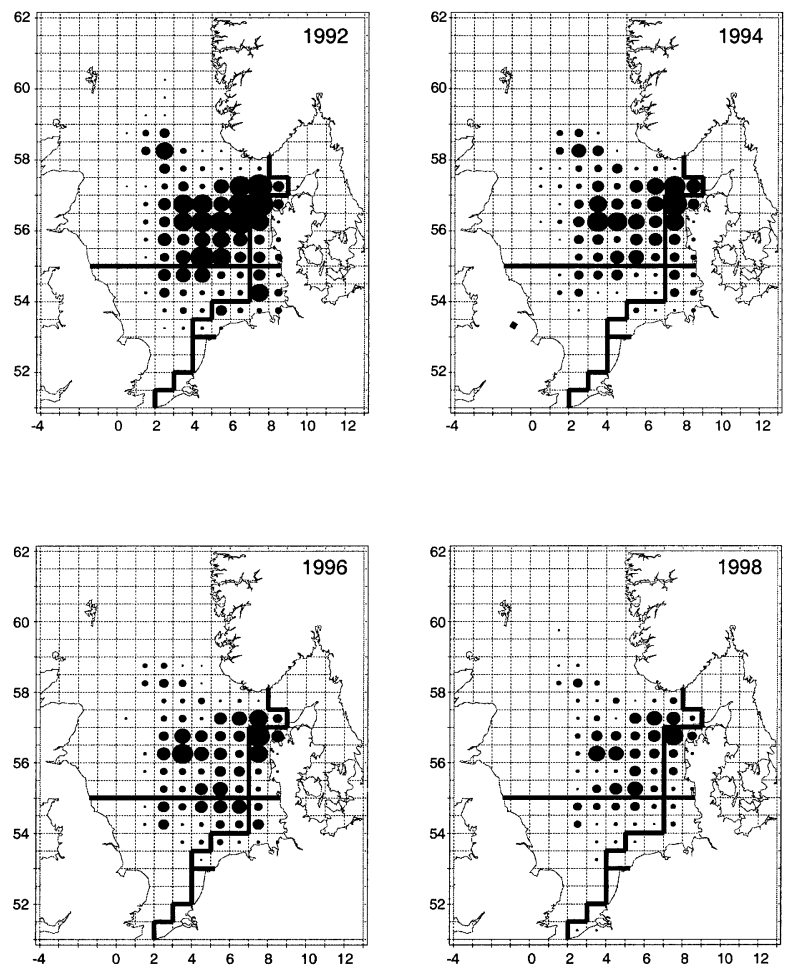

Longitude

Lat. $\mathbf{N}$
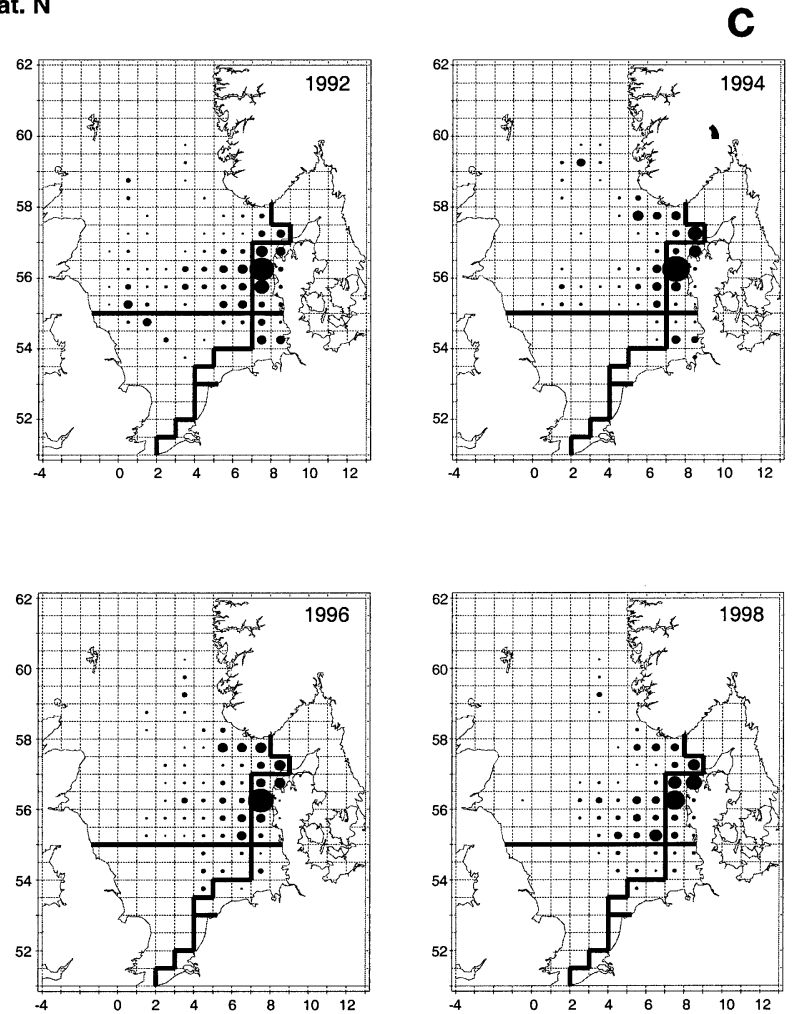

Longitude
Lat. $\mathbf{N}$

b
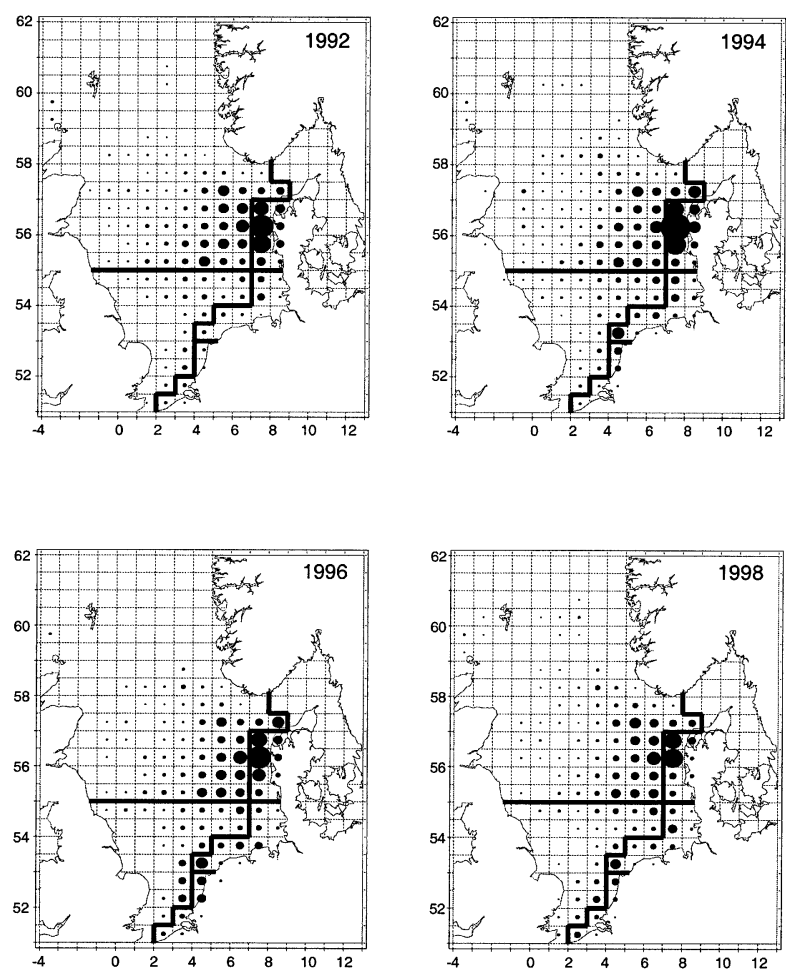

Longitude

Lat. $\mathbf{N}$
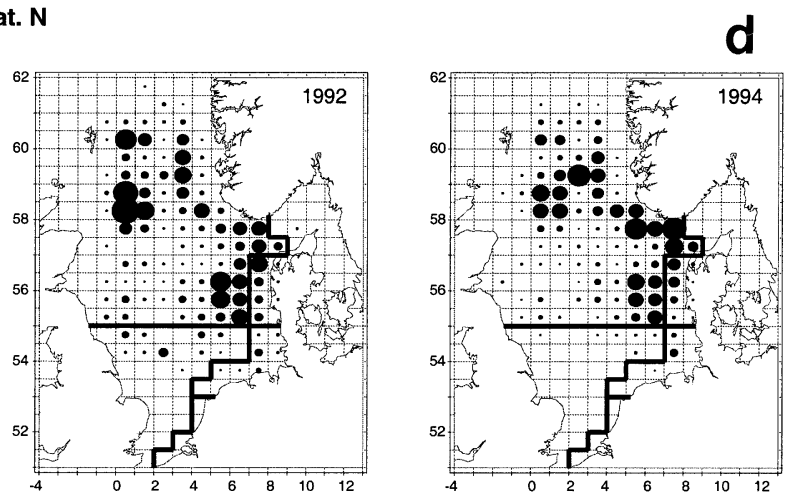

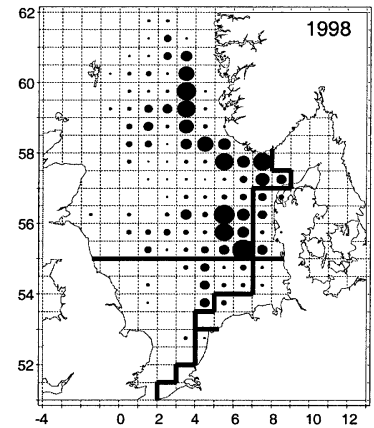

Longitude

Fig. 2. Spatial distribution of the fishing effort (number of days fishing) developed in the North Sea, in the years 1992 , 1994,1996 , 1998. a) the Danish seiners; b) the Danish gill-netters; c) the small Danish otter-trawlers (horsepower included in the range 0-300 hp); d) the large Danish otter-trawlers (horsepower greater than $300 \mathrm{hp}$ ). 
Lat. $\mathbf{N}$
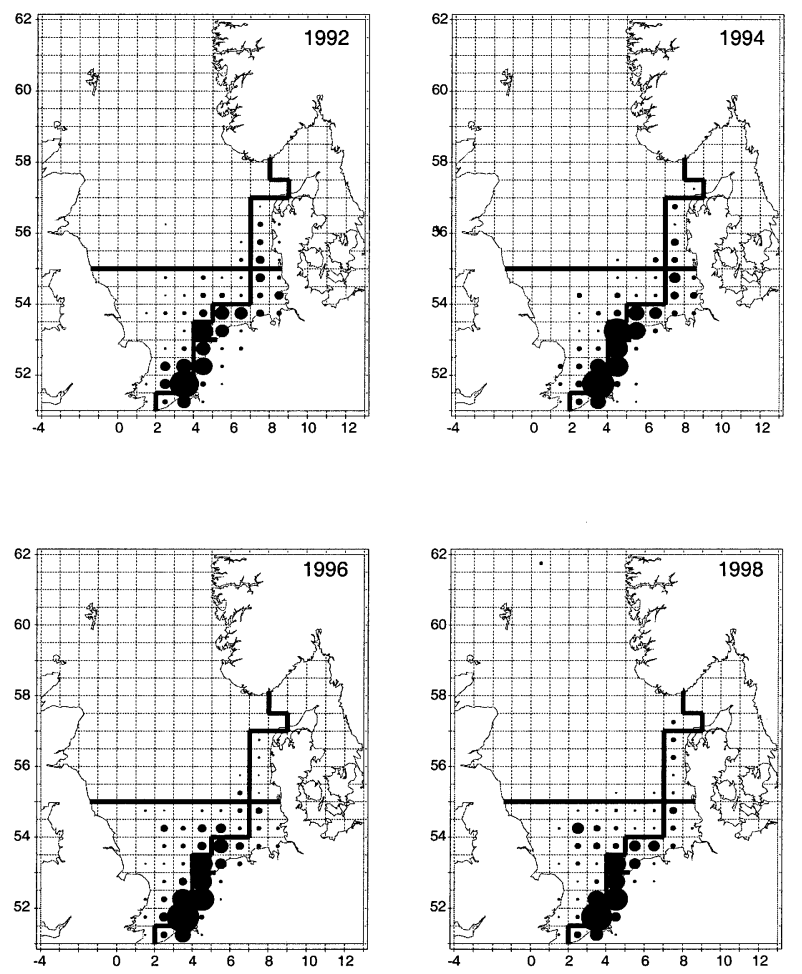

Longitude
Lat. $\mathbf{N}$
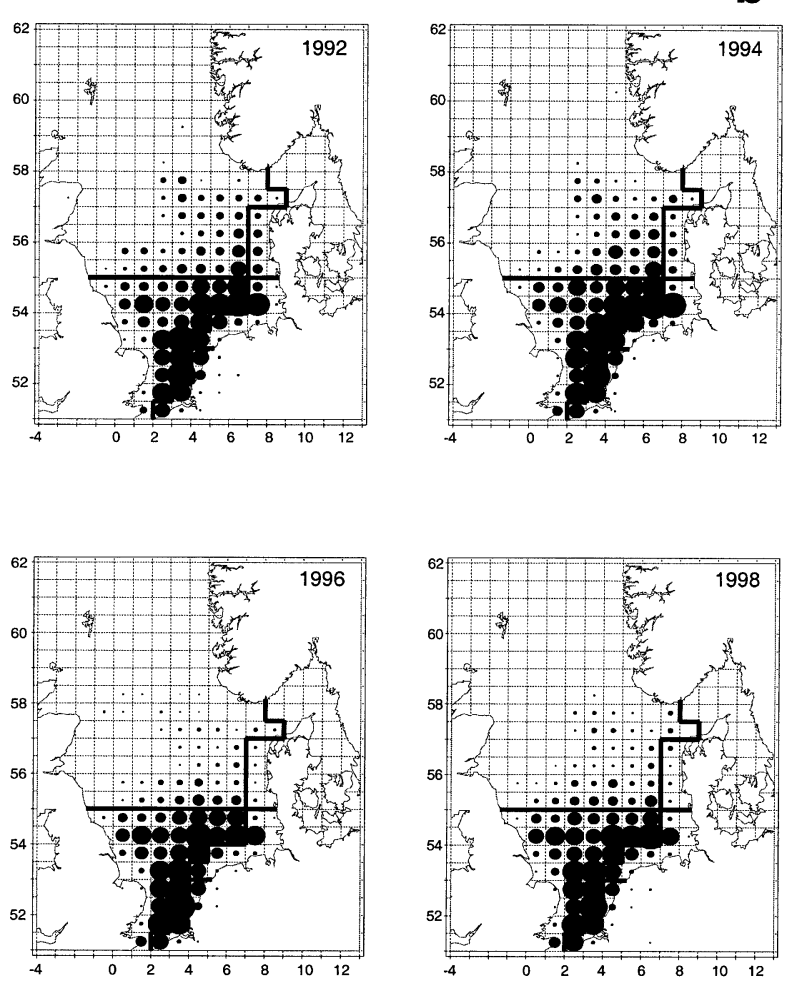

Longitude

Fig. 3. Spatial distribution of the fishing effort (number of days fishing) developed in the North Sea, in years 1992, 1994, $1996,1998$. a) the small Dutch beam-trawlers (horsepower included in the range 0-300 hp); b) the large Dutch beam-trawlers (horsepower greater than $300 \mathrm{hp}$ ).

initially investigated the first quarter of the year. Since 1991, the trawl used by each country has been made standard (GOV trawl). It is also since 1991 that IBTS investigates each quarter of the year. Each cruise is carried out by exploring a random sample of ICES squares. Each sampled rectangle is investigated once or twice per quarter by two different countries. Each haul lasts about 30 minutes. The IBTS abundance index is calculated as the catch in weight extrapolated to one hour of fishing. The IBTS is primarily designed to provide fishery-independent abundance indices of gadoids (cod, haddock and whiting). Substantial amounts of plaice are also sampled during IBTS, so that abundance indices could also be estimated relative to this species ICES, 1999a) We consider in this study the IBTS abundance indices of cod and plaice collected during the first quarter of each year.

The DBTS surveys in the North Sea began in 1985 using RV Isis. The stations are allocated over the fishable ICES rectangles on a 'pseudo-random' basis to ensure that there is a reasonable spread within each rectangle. Each ICES rectangle is sampled up to three times a year. No attempt is made to return to the same tow positions each year. In order to minimise the problem of haul variation which can occur if sampling takes place in the spring when fish are aggregated for spawning the survey is carried out in August and September when fish are distributed over the summer fishing grounds. Towing speed is 4 knots for a tow duration of 30 minutes and fishing occurs during daylight only. The fishing gear used is a pair of $8-\mathrm{m}$ beam trawls rigged with nets of 120-mm and 80-mm stretched mesh in the body and 40-mm stretched mesh cod-ends. The DBTS abundance index is calculated as the catch in weight per hour of fishing. The national survey DBTS is only used here to assist the analysis of the Dutch flatfish fishery.

\subsubsection{Coherence between commercial and survey information}

Survey data are available over the first (IBTS) or the third (DBTS) quarter, while commercial CPUE data are available all year round. In order to match temporally the commercial fishing period and the surveys, we selected CPUE data from the first quarter, when those are combined with survey information supplied by the IBTS. Likewise, we selected CPUE data from the third quarter, when those are combined with survey information supplied by the DBTS.

The spatial cover and sampling design of ICES rectangles differ between the IBTS, the DBTS and the commercial vessels. In order to allow combining information from both surveys and commercial trips, CPUE (from commercial vessels) and abundance indices (from survey) have been averaged over fishing hauls and extrapolated to the whole ICES rectangle to which they belong. 
The procedure described above allows matching temporally and spatially survey information with commercial CPUE data.

\section{Methods}

The main scope of this study is to address the impact of area-based management on fishing efficiency, and more precisely to assess whether reduced fishing activity and competition across fishing vessels, resulting from areabased management, could increase the fishing efficiency of remaining vessels Gillis and Peterman. 1998: Rijnsdorp et al. 2000). In order to address the issue, it is necessary to calculate time- and space-dependent indices of fishing efficiency.

A traditional approach to identify annual trends in fishing efficiency devotes attention to the relationship between partial fishing mortality (F) and fishing effort for a given stock and a given fleet Cook and Armstrong. 1985: Gascuel et al. 1993: Millischer et al. 1999. Partial F is calculated as the product between total $\mathrm{F}$ and the ratio between partial and total landings. Estimates of total $\mathrm{F}$ are usually derived from stock assessment analyses which, in the examples quoted above are the Virtual Population Analysis (VPA) Cook and Armstrong. 1985) and the eXtended Survivors Analysis (XSA) [Millischer et al. 1999. There are, however, two limitations to this approach based on estimates derived from any stock assessment procedure, including those quoted above. First, the reliability of the F estimates in the non-converged part of the time series is questionable, particularly when the $\mathrm{F}$ trajectories are prone to strong systematic retrospective patterns Darby and Flatman, 1994. Mohn 1999. Second, it is generally not possible to partition directly total $\mathrm{F}$ across geographical areas, unless assuming homogeneous stock distribution over the entire assessment area. Such an assumption is unlikely to apply to the North Sea stocks (ICES, 1999a) and this approach has consequently not been pursued.

A second approach (Marchalet al, 2001a) estimates time trends in fishing efficiency for any vessel by analysing the difference between the log-CPUE of the vessel and the average log-CPUE of a set of reference vessels (reference fleet) belonging to the fleet under examination. The reference vessels are chosen with regards to their stability over time. If a set of steady vessels could be found for each fleet, then the time variations in log-CPUE for these reference vessels should be consistent with stock dynamics. This analysis depends much on the ability to identify a set of reference vessels. If reference fleets had to be identified for each of the management areas under investigation, they would likely have to be made up of vessels having different attributes and behaviour. For example, Figs. 2 and 3 suggest that vessels fishing in areas 4 and 5 are in average bigger than those fishing in areas 1,2 and 3. Thus it is doubtful whether indices of fishing efficiency based on different reference fleets could be comparable across management areas. As a result, this approach could not be carried out for the purpose of the present investigation.

In order to address the time and spatial scale requirements of this investigation, an alternative two-step ap proach, which builds on Marchal et al_ (2001b), has been carried out in this study. This approach is based on four assumptions:

- There exist some reliable survey abundance indices, reflecting the temporal and spatial distribution of stock density.

- The fishing power of any vessel may be broken down into two components: fishing capacity (i.e., the vessel effect) and fishing efficiency (i.e., the fishermen effect). This definition is consistent with Laurec and Le Guen 1981). Gascuel et al. (1993). Millischer et al. (1999). and Marchal et al. (2001a.b).

- The fishing capacity of a commercial vessel $(v)$ harvesting species $(s)$ is entirely driven by its horsepower (h). A consequence of this assumption is that the fishing capacity of any vessel will be constant over time, unless it changes horsepower, in which case it will be considered as another vessel.

- The fishing efficiency of a commercial vessel (v) harvesting species $(s)$ varies between years and across spatial units. A consequence of the second and fourth assumptions is that time and spatial dynamics in fishing power are entirely consistent with those of fishing efficiency.

We define an index of fishing power, for any fishing vessel, harvesting a given species in a given year and in a given ICES rectangle, as the log-CPUE of the vessel relative to some external survey abundance index Marchal et al. 2001b). Unlike the two previously mentioned methods, this approach allows calculating the fishing power of any vessel, in any ICES rectangle, on which survey information is available. The idea of using the ratio of CPUE to fish density within a spatial unit is to cancel out stock abundance effects. The main limitation of this methodology is that stock abundance indices provided by research surveys are generally prone to high variability Byrne et al. 1981. Helser and Hayes, 1994). Despite this, research surveys provide an invaluable, and sometimes unique, source of information on stocks, which is also incorporated in stock assessment procedures (ICES, 1999a).

Given the first assumption, the fishing power (J) of a commercial vessel $v$, harvesting species $s$ in year $y$ and in ICES rectangle $i$ may then be expressed by equation (1)

$$
\mathrm{J}(v, s, y, i)=\ln [\mathrm{U}(v, s, y, i)]-\ln [\mathrm{I}(s, y, i)]
$$

where $\mathrm{U}$ is the commercial CPUE of vessel $v$ and I refers to the survey abundance index relative to species $s$. As described in the 'Research surveys' subsection, I is defined in average catch per hour and per ICES rectangle. Unlike the traditional definition of fishing power (Beverton and 
Holt. 1957: Robson. 1966, J has a spatial component. This spatial component is independent of the spatial distribution of stock density, since stock abundance effects have been cancelled out in defining J. Thus, the spatial component of $\mathrm{J}$ is used specifically in this study to reflect the effect on the vessels' fishing efficiency of their competition for common fishing grounds.

Given the above assumptions, the index of fishing power $\mathrm{J}$ may also be formulated by

$$
\mathrm{J}(v, s, y, i)=\mathrm{K}+\ln [\mathrm{FC}(h, s)]+\ln [\mathrm{FE}(s, y, i)]
$$

where $\mathrm{K}$ is a constant, while $\mathrm{FC}, \mathrm{FE}$ and $h$ respectively refer to the fishing capacity, fishing efficiency and horsepower relative to vessel $v$.

The indices of fishing power $(\mathrm{J})$, which are available by vessel, species, year and ICES rectangle, are then analysed by general linear model (GLM) for each combination of species, fleet (i.e., one subset of vessels) and management area (i.e., one subset of ICES squares). External variables include horsepower, year and ICES rectangle, all discrete variables. The horsepower-effect will here be interpreted as fishing capacity (third assumption). Since stock abundance effects have been cancelled out in J, the year-effect will be interpreted as annual trends in fishing efficiency (fourth assumption). Two spatial effects may be derived from this analysis, as differences in fishing power and efficiency may occur within management areas (ICES rectangle effect) and across management areas. Since stock abundance effects have been cancelled out in $J$, these spatial effects may be interpreted as spatial discrepancies in fishing efficiency either within management areas (ICES rectangle effect) or between management areas (fourth assumption). In order to meet the requirements of this study, it is more desirable to contrast fishing efficiencies between management areas. The point of using ICES rectangles as an external factor to the GLMs is then to cancel out any spatial effect that may occur within each management area, so as to better contrast fishing efficiencies between management areas. Two GLM models have been considered for each combination of species, fleet and management area.

- Model 1

$$
\mathbf{J}=\mu+\alpha_{h}+\beta_{y}+\gamma_{i}+\chi_{y, i}+\varepsilon_{h, y, i}
$$

- Model 2

$$
\mathbf{J}=\mu+\alpha_{h}+\beta_{y}+\gamma_{i}+\varepsilon_{h, y, i}
$$

where $\mu$ is the average term; $\alpha_{h}$, and $\gamma_{i}$ the terms relative to the effect of the $i^{\text {th }}$ horsepower category and $i^{\text {th }}$ ICES rectangle respectively, $\beta_{y}$ the term relative to the effect of the $y^{\text {th }}$ year. $\varepsilon$ is the model residual. $\chi_{y, i}$ is the interaction term between variables year and ICES rectangle. Model 1 is the most comprehensive, but is not tractable for the purpose of our analysis. In particular, it is not possible to disentangle temporal and spatial effects. Model 2 is the most basic model, since it ignores any possible correlation between variables. Comparing the goodness of fit between models 1 and 2 may be useful to appraise the contributions of variable interactions to the variations in fishing efficiency.

Comparing equations (2) and ( $3 b$ ), $\alpha_{h}$ may be considered as a proxy for fishing capacity, while $\beta_{y}$ reflects annual variations in fishing efficiency, averaged over ICES squares. The time dynamics of $\beta_{y}$ are then examined and compared across fleets, species and management areas. $\beta_{y}$ is calculated for the Danish and Dutch fleets harvesting cod and plaice, using the IBTS indices of stock abundance. In addition, $\beta_{y}$ is calculated for the Dutch fleets harvesting plaice and sole, based on the DBTS indices of stock abundance.

\section{Results}

The number of observations and the coefficients of determination (R-Square) derived from the different GLM analyses are respectively shown in Tables 1 and 2 . R-Squares derived from model 1 are higher than $50 \%$ for 27 out of the 36 combinations country*area*fleet*species* survey. R-Squares derived from model 2 are substantially lower than those derived from model 1 . This observation indicates that the year-effect interacts with the ICES rectangle-effect. In other words, annual trends in efficiency are different across ICES rectangles belonging to the same management area. However, Figs. 4 and 5 indicate that the residuals derived from model 2 are generally not correlated to predicted values. Only the residuals calculated relative to the Danish fleets in area 4 are negatively correlated to the predictions, while their scatter appears to be broken up into two separate sets of points (Fig. 4). Fishing efficiency trends estimated for the Danish fleets fishing in area 4 should hence be interpreted cautiously.

Fig. 6 shows the annual trends in the fishing efficiency of the Danish fleets operating in management areas 1, 4 and 5. The time series relative to the fishing efficiency of the fleets operating in area 4 are hardly interpretable, as discussed in the above paragraph. The fishing efficiency of both gillnetters and Danish seiners fishing in the plaice box (area 1) has overall increased over the period of investigation. However, the trend in efficiency of Danish seiners is obscured by large standard errors around the estimates. The fishing efficiency of both gill-netters and Danish seiners fishing outside the plaice box (area 5) has remained stable over the same period. The fishing efficiency of gill-netters harvesting cod was lowest inside the plaice box in 1991, but it increased consistently to reach the same level as in area 5 in 1997. It is not possible to identify any particular pattern in the dynamics of the fishing efficiency of the trawlers fishing inside and outside the plaice box. It is not clear why the fishing efficiency of all the fleets operating in the plaice box has dropped in 1998 in area 1.

Fig. 7 shows the annual trends in the fishing efficiency of the Dutch fleets operating in management areas 2,3,4 and 
Table 1

Number of observations available to perform the GLM analyses for each combination of country, management area, fleet, species and research survey used to supply stock abundance indices

\begin{tabular}{|c|c|c|c|c|c|}
\hline \multicolumn{3}{|c|}{ No. observations } & \multirow[b]{2}{*}{ Species } & & \multirow{2}{*}{$\begin{array}{c}\text { Research survey } \\
\text { IBTS }\end{array}$} \\
\hline Country & Area & Fleet & & DBTS & \\
\hline \multirow[t]{16}{*}{ Denmark } & \multirow[t]{6}{*}{1} & DS & $\operatorname{cod}$ & & 222 \\
\hline & & & plaice & & 242 \\
\hline & & $\overline{\mathrm{GN}}$ & cod & & 1346 \\
\hline & & & plaice & & 1392 \\
\hline & & OTB $<0-300 \mathrm{hp}>$ & cod & & 233 \\
\hline & & & plaice & & 256 \\
\hline & \multirow[t]{8}{*}{4} & DS & $\operatorname{cod}$ & & 2375 \\
\hline & & & plaice & & 2567 \\
\hline & & GN & cod & & 3756 \\
\hline & & & plaice & & 3826 \\
\hline & & OTB $<0-300 \mathrm{hp}>$ & cod & & 186 \\
\hline & & & plaice & & 210 \\
\hline & & OTB $<300+$ hp $>$ & cod & & 1291 \\
\hline & & & plaice & & 964 \\
\hline & \multirow[t]{2}{*}{5} & GN & $\operatorname{cod}$ & & 865 \\
\hline & & & plaice & & 954 \\
\hline \multirow[t]{15}{*}{ Netherlands } & \multirow[t]{3}{*}{2} & $\mathrm{TBB}<0-300 \mathrm{hp}>$ & $\operatorname{cod}$ & & 232 \\
\hline & & & plaice & 225 & 176 \\
\hline & & & sole & 219 & \\
\hline & \multirow[t]{3}{*}{3} & TВB $<0-300 \mathrm{hp}>$ & $\operatorname{cod}$ & & 1051 \\
\hline & & & plaice & 1201 & 729 \\
\hline & & & sole & 1166 & \\
\hline & \multirow[t]{3}{*}{4} & $\mathrm{TBB}<300+\mathrm{hp}>$ & cod & & 1161 \\
\hline & & & plaice & 511 & 1158 \\
\hline & & & sole & 463 & \\
\hline & \multirow[t]{6}{*}{5} & $\mathrm{TBB}<0-300 \mathrm{hp}>$ & cod & & 934 \\
\hline & & & plaice & 995 & 799 \\
\hline & & & sole & 970 & \\
\hline & & $\mathrm{TBB}<300+\mathrm{hp}>$ & $\operatorname{cod}$ & & 13621 \\
\hline & & & plaice & 8190 & 14072 \\
\hline & & & sole & 8155 & \\
\hline
\end{tabular}

GN: gill-netters; DS: Danish seiners; OTB $<0-300$ hp $>$ : otter-trawlers using a horsepower of maximum 300 hp; OTB $<300+>$ otter-trawlers using a horsepower exceeding $300 \mathrm{hp}$; TBB $<0-300 \mathrm{hp}>$ : beam-trawlers using a horsepower of maximum $300 \mathrm{hp}$; TBB $<300+>$ beam trawlers using a horsepower exceeding $300 \mathrm{hp}$.

5. It should be noted that the standard errors associated to fishing efficiency estimates are small, except for the estimates of the small beam-trawlers in the most recent years, when those are derived from IBTS abundance indices. It is generally not possible to detect contrasts in the dynamics of the fishing efficiency of the small beam-trawlers operating inside (area 2) and outside (area 5) the plaice box, whatever the survey abundance indices being used. The fishing efficiency of the small beam-trawlers harvesting cod in the 12 nautical mile zone (area 3) was lower than in the other management areas (2 and 5) over the period 1992-1994, and then increased above the level estimated in areas 2 and 5 over the period 1996-1998. However, this pattern is obscured by the large standard errors associated to the fishing efficiency estimates in areas 2 and 5 over the 1996-1998 period.

The fishing efficiency of the large beam-trawlers harvesting plaice in area 4 is consistently higher than in area 5 whatever the survey abundance indices being used. This result is unlikely to be imputable to differences in management regimes between these two areas, since mesh size regulations in area 4 are more constraining than in area 5 . The rationale underlying this discrepancy could lie on the grounds of differences in fleet behaviour, as debated in the discussion.

No differences in fishing efficiency dynamics could be detected across management areas for either small or large beam-trawlers harvesting sole in the North Sea. 
Table 2

R-Squares derived from the two GLM analyses (referred to as models 1 and 2), for each combination of country, management area, fleet, species and research survey used to supply stock abundance indices

\begin{tabular}{|c|c|c|c|c|c|c|c|}
\hline \multirow[t]{2}{*}{ R-Square } & & & & \multicolumn{4}{|c|}{ Research survey / GLM model } \\
\hline & & & & DBTS & DBTS & IBTS & IBTS \\
\hline Country & Area & Fleet & Species & Model 1 & Model 2 & Model 1 & Model 2 \\
\hline \multirow[t]{16}{*}{ Denmark } & \multirow[t]{6}{*}{1} & DS & $\operatorname{cod}$ & & & 0.31 & 0.20 \\
\hline & & & plaice & & & 0.56 & 0.37 \\
\hline & & GN & $\operatorname{cod}$ & & & 0.45 & 0.19 \\
\hline & & & plaice & & & 0.41 & 0.31 \\
\hline & & OTВ $<0-300 \mathrm{hp}>$ & $\operatorname{cod}$ & & & 0.38 & 0.25 \\
\hline & & & plaice & & & 0.55 & 0.42 \\
\hline & \multirow[t]{8}{*}{4} & DN1 & $\operatorname{cod}$ & & & 0.42 & 0.18 \\
\hline & & & plaice & & & 0.47 & 0.28 \\
\hline & & GN & $\operatorname{cod}$ & & & 0.50 & 0.17 \\
\hline & & & plaice & & & 0.50 & 0.33 \\
\hline & & OTB $<0-300 \mathrm{hp}>$ & $\operatorname{cod}$ & & & 0.87 & 0.45 \\
\hline & & & plaice & & & 0.81 & 0.45 \\
\hline & & OTB $<300+h p>$ & $\operatorname{cod}$ & & & 0.59 & 0.23 \\
\hline & & & plaice & & & 0.75 & 0.59 \\
\hline & \multirow{2}{*}{5} & GN & $\operatorname{cod}$ & & & 0.66 & 0.30 \\
\hline & & & plaice & & & 0.62 & 0.34 \\
\hline \multirow[t]{15}{*}{ Netherlands } & \multirow[t]{3}{*}{2} & ТВВ $<0-300 \mathrm{hp}>$ & $\operatorname{cod}$ & & & 0.42 & 0.31 \\
\hline & & & plaice & 0.74 & 0.64 & 0.61 & 0.54 \\
\hline & & & sole & 0.80 & 0.73 & & \\
\hline & \multirow[t]{3}{*}{3} & ТВВ $<0-300 \mathrm{hp}>$ & $\operatorname{cod}$ & & & 0.78 & 0.55 \\
\hline & & & plaice & 0.37 & 0.17 & 0.24 & 0.15 \\
\hline & & & sole & 0.81 & 0.65 & & \\
\hline & \multirow[t]{3}{*}{4} & $\mathrm{TBB}<300+\mathrm{hp}>$ & $\operatorname{cod}$ & & & 0.88 & 0.61 \\
\hline & & & plaice & 0.91 & 0.81 & 0.86 & 0.61 \\
\hline & & & sole & 0.67 & 0.58 & & \\
\hline & \multirow[t]{6}{*}{5} & ТВВ $<0-300 \mathrm{hp}>$ & $\operatorname{cod}$ & & & 0.77 & 0.49 \\
\hline & & & plaice & 0.59 & 0.46 & 0.53 & 0.26 \\
\hline & & & sole & 0.84 & 0.64 & & \\
\hline & & $\mathrm{TBB}<300+\mathrm{hp}>$ & $\operatorname{cod}$ & & & 0.85 & 0.35 \\
\hline & & & plaice & 0.90 & 0.75 & 0.78 & 0.40 \\
\hline & & & sole & 0.91 & 0.70 & & \\
\hline
\end{tabular}

GN: gill-netters; DS: Danish seiners; OTB $<0-300 \mathrm{hp}>$ : otter trawlers using a horsepower of maximum $300 \mathrm{hp}$; OTB $<300+>$ otter-trawlers using a horsepower exceeding $300 \mathrm{hp}$; TBB $<0-300 \mathrm{hp}>$ : beam-trawlers using a horsepower of maximum $300 \mathrm{hp}$; TBB $<300+>$ beam-trawlers using a horsepower exceeding $300 \mathrm{hp}$.

\section{Discussion}

The main outcome of this study is that the fishing efficiency of some of the fisheries under investigation has followed contrasted trends inside and outside the set of ICES rectangles representing the plaice box. Thus, the fishing efficiency of both gill-netters and, to some extent, Danish seiners, has overall increased inside the plaice box, whilst remaining relatively stable outside. By contrast, the fishing efficiency of the other exemption fleets (small otterand beam-trawlers) has apparently been subject to few changes over the period of investigation. These issues give birth to two questions. First, to what extent has the plaice box, which has been three-quarterly and fully implemented in 1994 and 1995 respectively, contributed to increasing the fishing efficiency of the Danish seiners and gill-netters? Second, if the plaice box had an effect on gill-netters and Danish seiners, why would it not increase the fishing efficiency of small trawlers?

In order to demonstrate the effect of the plaice box on fishing efficiency, it would be critical to ensure both (i) fishing efficiency has hereby been properly modelled so that it does not depend on potentially area-dependent factors including stock density, fishing capacity and fishing activity and, (ii) factors other than management that may influence fishing efficiency (e.g., fishermen's skill) are areaindependent.

In relation to point (i), it has hereby been assumed that survey indices, total horsepower and number of days fishing 

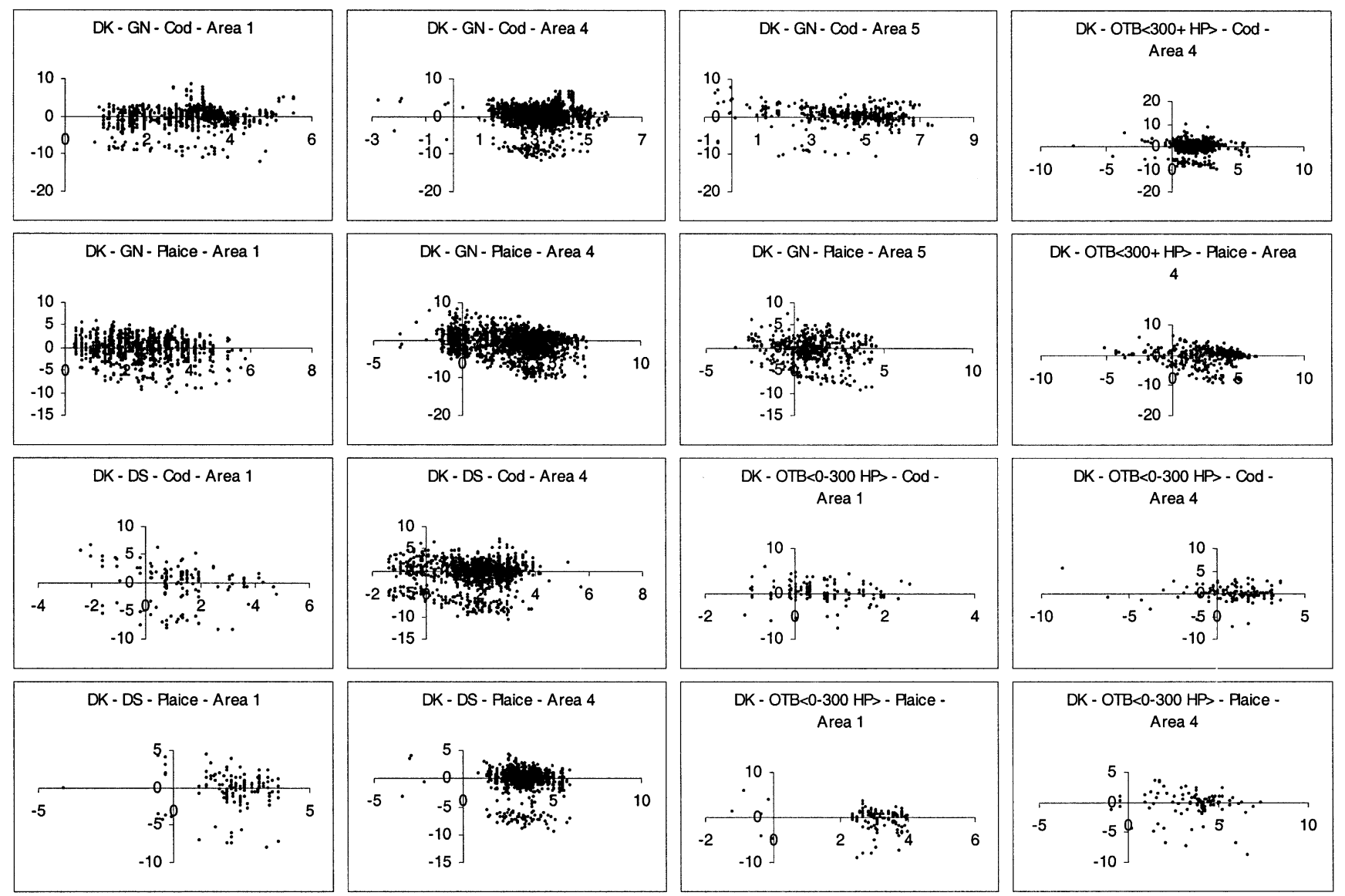

Fig. 4. Representation of the residuals ( $\mathrm{Y}$ axis) versus predictions (X axis), as derived from the GLM analysis, performed without interactions between explanatory variables (model 2), of the fishing power of the Danish fleets harvesting cod and plaice in the North Sea management areas 1, 4 and 5. DK: Denmark; GN: gill-netters; DS: Danish seiners; OTB $<0-300 \mathrm{hp}>$ : otter-trawlers using a horsepower of maximum $300 \mathrm{hp}$; OTB $<300+\mathrm{hp}>$ otter-trawlers using a horsepower exceeding $300 \mathrm{hp}$. The stock abundance indices used to carry out the analyses are derived from IBTS.

could be used as proxies to stock density, fishing capacity and fishing activity.

Although survey indices are used to perform stock assessments $\amalg$ CES. 1999a they are reckoned to be prone to variability (Byrne et al. 1981: Helser and Hayes, 1994). These indices represent however the best fisheryindependent source of information on the spatial and temporal distribution of the stocks under examination.

An evaluation of the determinants of fishing capacity has been carried out by the Scientific, Technical and Economic Committee for Fisheries (STECF) for European Union countries, including Denmark and Holland Anonymows $\mathrm{bOOab}$. Total horsepower, or any variable well correlated with horsepower (i.e., gross tonnage, vessel length), is generally accepted as a sensible estimate of fishing capacity for beam-trawlers. However the fishing capacity of other fleets, including gill-netters and otter-trawlers, is also likely to be affected by vessel age and/or net size, which could not be made available to this study.

The determinants of the fishing activity have also been reviewed by the STECF (Anonymous, 2000b) The group identified better candidates than the number of days fishing, such as the number of hours fishing (beam-trawlers), soaking time (gill-netters) or the number of sets (Danish seiners).

In relation to point (ii), there is some evidence that fishermen operating in given areas could more skilful than others who fish elsewhere. Thus, the fishing efficiency of large beam-trawlers harvesting plaice is greater in the $100-\mathrm{mm}$ mesh size area (area 4) than in the $80-\mathrm{mm}$ mesh size derogation area (area 5), although the first is more constraining by mesh size regulations than the latter. This discrepancy could be interpreted as differences in fleet behaviour. Fishing in area 4 requires more travelling time and hence greater operating costs for the Dutch fishermen, compared to fishing in area 5. The density of plaice is estimated to be greater in the northern part of the North Sea than in the Southern part while sole, the main target species of beam-trawlers, is rather concentrated in the southern North Sea ICES. 1999a,b). Therefore, it may be anticipated that fishermen fishing in area 4 configure their fishing trip to target plaice, in order to make their fishing trip profitable. As a result, these fishermen could be more efficient, in relation to plaice fishing, than those fishing in area 5 .

If the plaice box had some positive effect on the fishing efficiency of the exemption fleets, there are at least two 

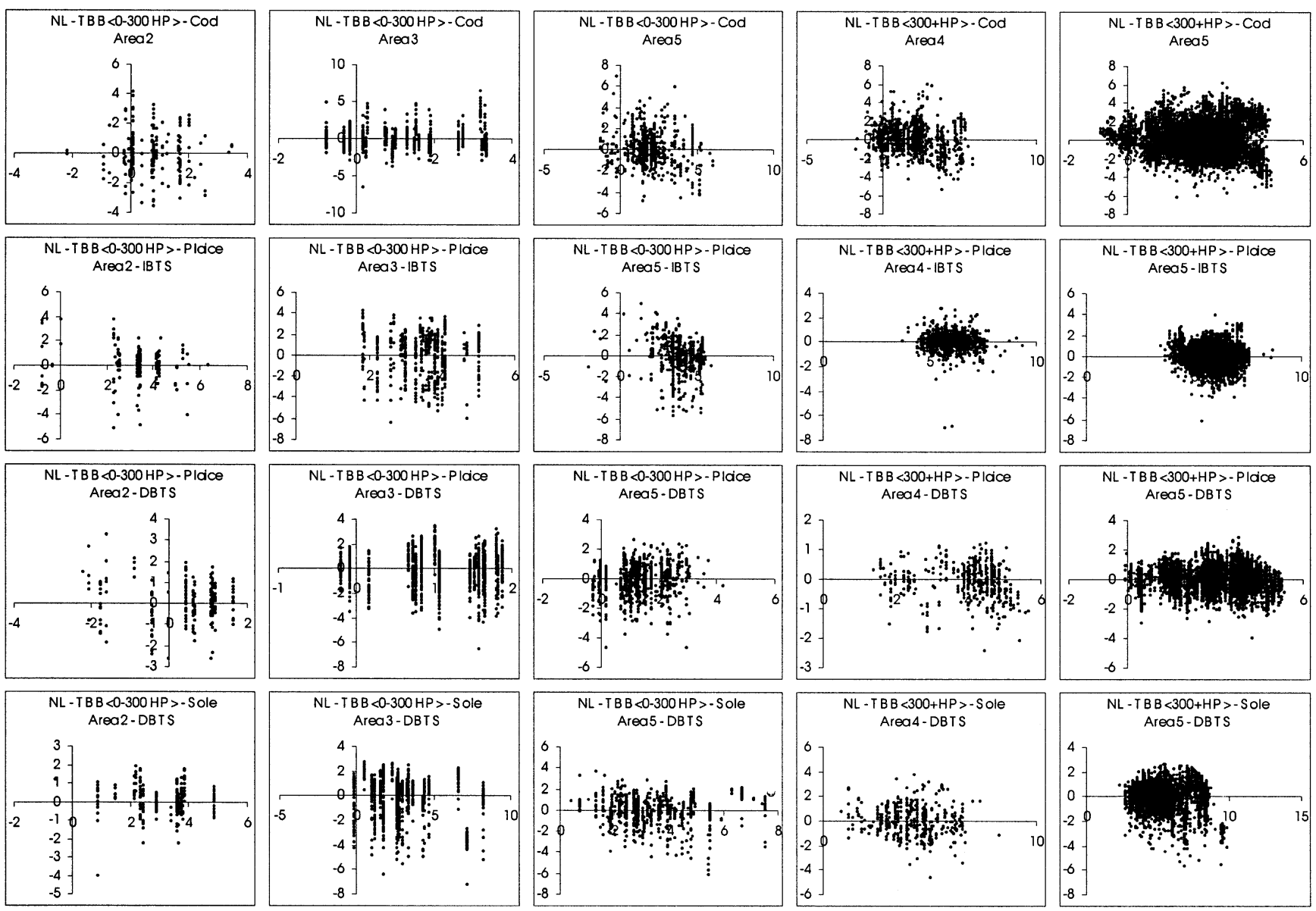

Fig. 5. Representation of the residuals (Y axis) versus predictions (X axis), as derived from the GLM analysis, performed without interactions between explanatory variables (model 2), of the fishing power of the Dutch fleets harvesting cod, plaice and sole in the North Sea management areas 2, 3, 4 and 5. NL: The Netherlands; TBB $<0-300 \mathrm{hp}>$ : beam-trawlers using a horsepower of maximum $300 \mathrm{hp}$; TBB $<300+$ hp $>$ beam-trawlers using a horsepower exceeding $300 \mathrm{hp}$. The stock abundance indices used to carry out the analyses are derived from IBTS and/or DBTS.
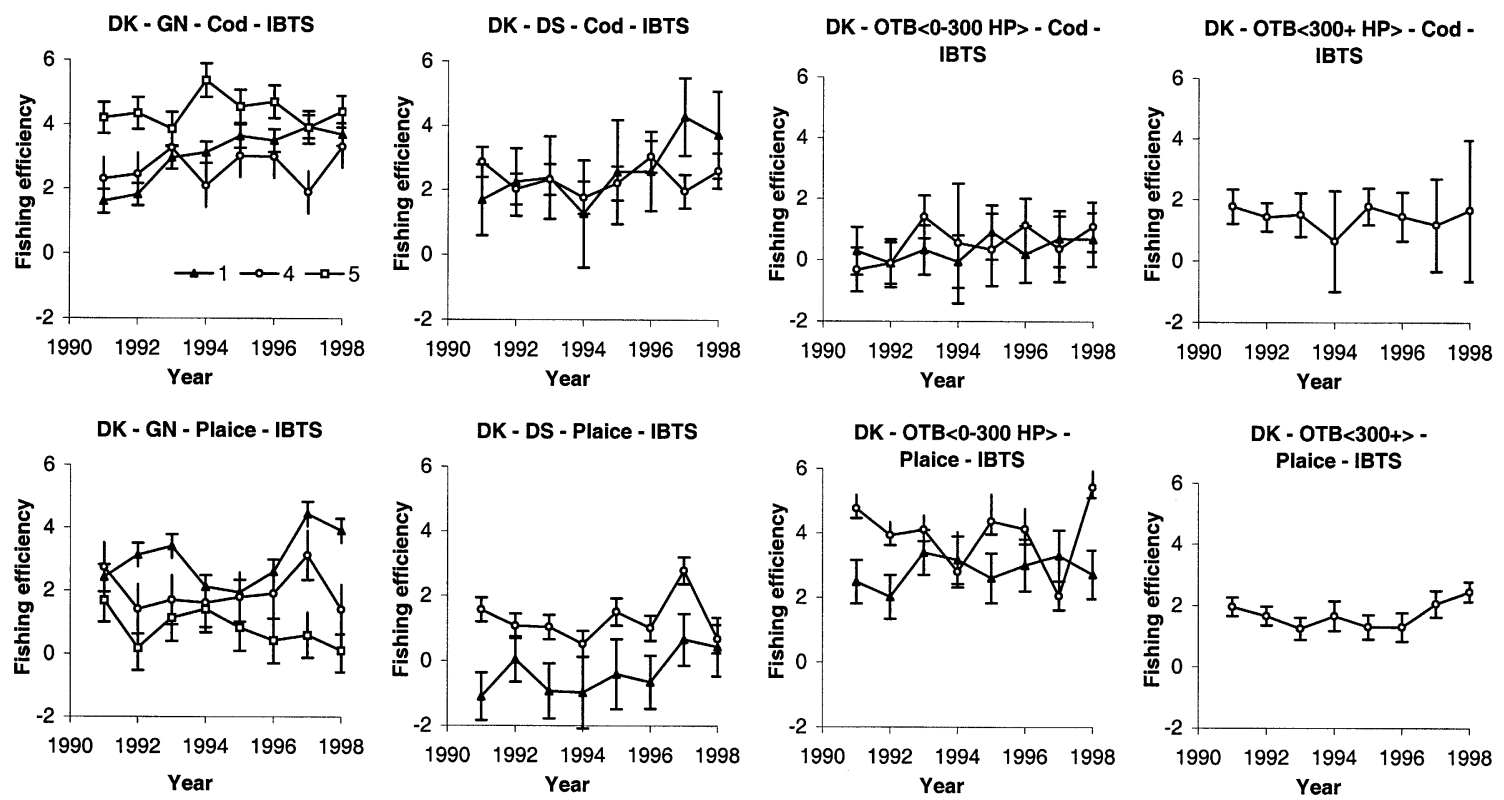

Fig. 6. Annual trends and associated error bars of the fishing efficiency of the Danish fleets harvesting cod and plaice in the North Sea management areas 1 (black triangle), 4 (white circle) and 5 (white square). DK: Denmark; GN: gill-netters; DS: Danish seiners; OTB $<0-300 \mathrm{hp}>$ : otter-trawlers using a horsepower of maximum $300 \mathrm{hp}$; OTB $<300+\mathrm{hp}>$ otter-trawlers using a horsepower exceeding $300 \mathrm{hp}$. 'IBTS' refers to the research survey, from which the abundance indices used to calculate fishing efficiencies have been derived. 

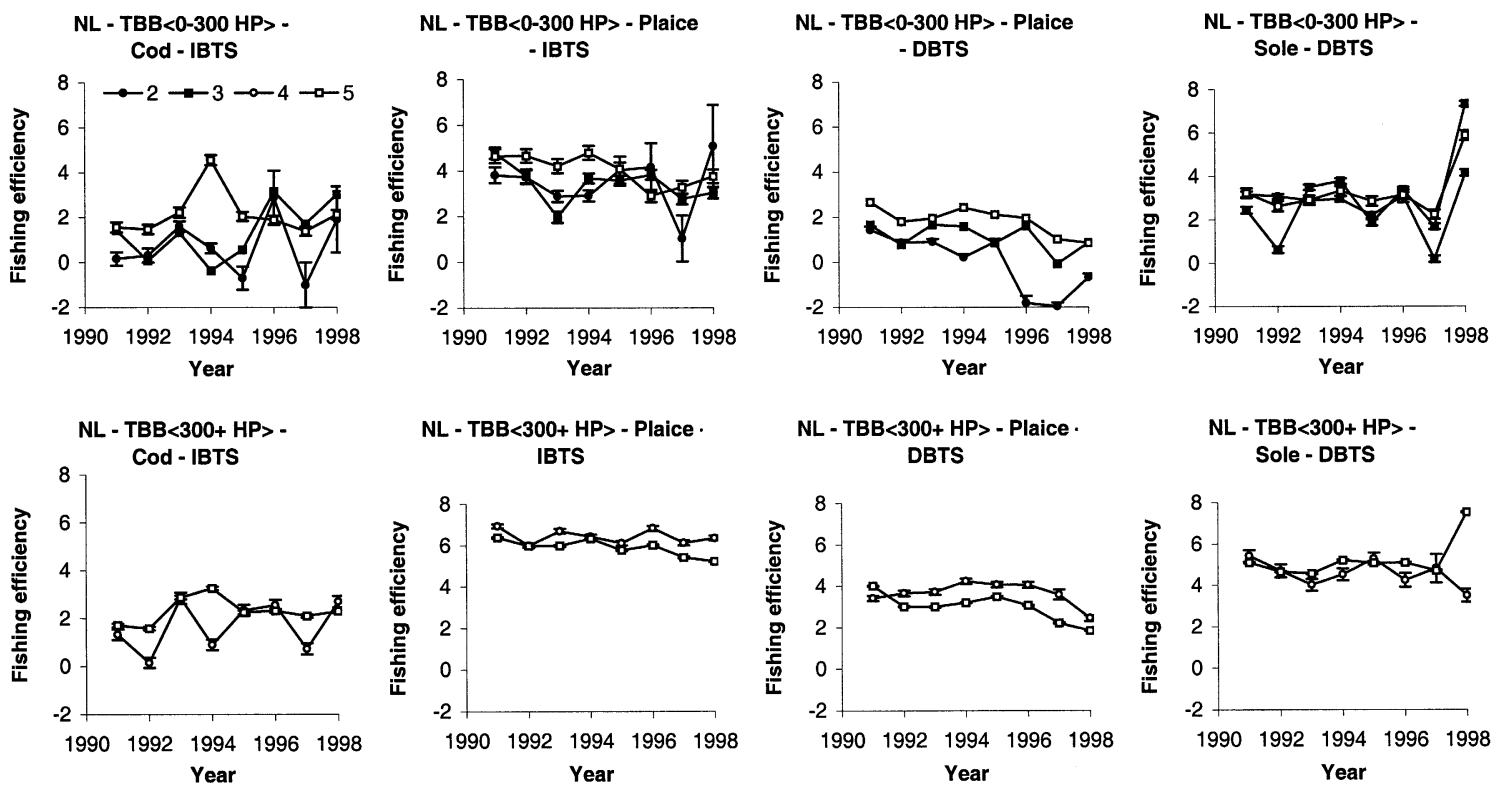

Fig. 7. Annual trends and associated error bars of the fishing efficiency of the Dutch fleets harvesting cod, plaice and sole in the North Sea management areas 2 (black circle), 3 (black square), 4 (white circle) and 5 (white square). NL: The Netherlands; TBB $<0-300$ hp $>$ : beam-trawlers using a horsepower of maximum $300 \mathrm{hp}$; TBB<300+ hp> beam-trawlers using a horsepower exceeding $300 \mathrm{hp}$. 'IBTS' and 'DBTS' refer to the research surveys, from which the abundance indices used to calculate fishing efficiencies have been derived.

reasons why this effect could not be observed for the small trawlers. First, the fishing effort of both beam- and ottertrawlers has been substantially reallocated in order to account for the partial mismatch between the official definition of the plaice box set up by the European Commission and the set of ICES rectangles used in this study to represent it. This approximation could prove too rough, and could alter our perception of the fishing efficiency of these trawling fleets. Second, in the case of the Dutch beamtrawlers, our perception of fishing efficiency dynamics could be perturbed by national management schemes. Thus, in The Netherlands, the national quotas are allocated over individual vessels by Individual Transferable Quota (ITQ), which are freely tradable and fully divisible Grafton, 1996. Salz_ 1996. As debated in Eascoe et_al_(2001) ITQ would have been expected to facilitate the transfer of quota and hence would have been expected to have improved effi ciency. However, the ITQ system also leads to a greater control over sale of landings, reducing the potential to land over-quota catch. As a result, the increased enforcement may have lead to an increase in over-quota discards and hence an apparent decrease in efficiency.

Overall, it is not possible here to determine the extent to which the plaice box has contributed to the apparent increase in the fishing efficiency of some of the exemption fleets, fishing on the grounds where management has been implemented. Actually, this limitation would apply to most biological analyses based on the comparison between impacted and non-impacted populations. Despite this, the outcome of this study brings some support to the conclusions of other studies, which have demonstrated that decreasing competitive vessel interactions, resulting from reduced fishing effort, could increase the fishing efficiency of remaining vessels Gillis and Peterman, 1998; Rijnsdorp Refining the outcomes of this study could be achieved through collecting more acute data on the determinants of fishing capacity (e.g., net size, vessel age) and fishing activity (e.g., soaking time, number of sets per day), and also through sharpening up the spatial resolution of the investigation.

A practical application of the outcomes of this investigation would be to evaluate the extent to which stock assessment diagnostics could be affected by trends in fishing efficiency, such as those shown in this study. Such an investigation is being made in a companion study.

\section{Acknowledgements}

This work has been funded by the European Union (DG XIV, study no. 98/027), while data from research surveys have been kindly supplied by the ICES. These supports are gratefully acknowledged.

\section{References}

Anonymous, 1997. Presidency compromise on technical conservation measures. Fisheries Council of the European Union, SN 4282/1/97 REV 1 (peche).

Anonymous, 1999. $8^{\text {th }}$ report of the Scientific, Technical and Economic Committee for Fisheries. Brussels, 20-26 April 1999. SEC, 932.

Anonymous, 2000a. Report from the Commission to the Council. Preparation for a mid term review of the Multi-annual Guidance Programmes (MAGP). COM(2000) 272. 
Anonymous, 2000b. $10^{\text {th }}$ report of the Scientific, Technical and Economic Committee for Fisheries. Brussels, 3-7 April 2000. SEC(2000) final draft.

Arnason, R., 1994. On catch discarding in fisheries. Mar. Resour. Econ. 9, 189-207.

Arreguin-Sanchez, F., 1996. Catchability: a key parameter for fish stock assessment. Rev. Fish Biol. Fish. 6, 221-242.

Arreguin-Sanchez, F., Pitcher, T.J., 1999. Catchability estimates and their application to the red grouper (Epinephelus morio) fishery of the Campeche Bank. Mexico. Fish. Bull. 97, 746-757.

Atran, S.M., Loesch, J.G., 1995. An analysis of weekly fluctuations in catchability coefficients. Fish. Bull. 93, 562-567.

Beverton, R.J.H., Holt, S.J., 1957. On the Dynamics of Exploited Fish Populations, MAFF Fishery Investigation Series II, XIX, HMSO, London.

Byrne, C.J., Azarovitz, T.R., Sissenwine, M.P., 1981. Factors affecting variability of research trawl surveys. Can. Spec. Publ. Fish. Aquat. Sci. $58,238-273$.

Chen, Y., Paloheimo, J.E., 1998. Can a more realistic model error structure improve the parameter estimation in modelling the dynamics of fish populations? Fish. Res. 38, 9-17.

Clark, C.W., 1980. Towards a predictive model for the economic regulation of commercial fisheries. Can. J. Fish. Aquat. Sci. 37, 1111-1129.

Cook, R.M., Armstrong, D.W., 1985. Changes in catchability of cod, haddock, and whiting associated with the Scottish seine-net fishery. J. Cons. Int. Explor. Mer 42, 171-178.

Crecco, V., Overholtz, W.J., 1990. Causes of density-dependent catchability for Georges Bank haddock (Melanogrammus aeglefinus). Can. J. Fish. Aquat. Sci. 47, 385-394.

Darby, C.D., Flatman, S., 1994. Virtual Population Analysis: version 3.1 (Windows/DOS) user guide. Information Technology Series, MAFF Directorate of Fisheries Research, Lowestoft, 1. pp. 85.

Deriso, R.B., Quinn II, T.J., Neal, P.R., 1985. Catch-age analysis with auxiliary information. Can. J. Fish. Aquat. Sci. 42, 815-824.

Fournier, D., Archibald, C.P., 1982. A general theory for analyzing catch at age data. Can. J. Fish. Aquat. Sci. 39, 1195-1207.

Gascuel, D., Fonteneau, A., Foucher, E., 1993. Analyse de l'évolution des puissances de pêche par l'analyse des cohortes: application aux senneurs exploitant l'albacore (Thunnus albacares) dans l'Atlantique Est. Aquat. Living Resour. 6, 15-30.

Gillis, D.M., Peterman, R.M., 1998. Implications of interference among fishing vessels and the ideal free distribution to the interpretation of CPUE. Can. J. Fish. Aquat. Sci. 55, 37-46.

Grafton, R.Q., 1996. Individual transferable quotas: theory and practice. Rev. Fish Biol. Fish. 6, 5-20.

Gulland, J.A., 1964. Catch per unit effort as a measure of abundance. Rapp. P.V. Réun. Cons. Int. Explor. 155, 66-70.

Helser, T.E., Hayes, D.B., 1994. Providing quantitative management advice from stock abundance indices based on research surveys. Fish. Bull. 93, 290-298.

Holden, M., 1994. The Common Fisheries Policy. Origin, Evaluation and Future. Fishing News Books. Trustees, The Buckland Foundation 1994. pp. 274.

Hovgård, H., 1996. Effect of twine diameter on fishing power of experimental gill nets used in Greenland waters. Can. J. Fish. Aquat. Sci. 53, 1014-1017.

ICES, 1999a. Report of the Working Group on the Assessment of Demersal Stocks in the North Sea and Skagerrak. ICES CM1999 ACFM 8. pp. 676 .
ICES, 1999b. Report of the workshop on the evaluation of the 'plaice box'. ICES CM1999 D:6. pp. 123.

Laurec, A., Le Guen, J.-C., 1981. Dynamiques des populations marines exploitées. CNEXO, Rapp. Scient. Techn., 45.

Lehodey, P., Marchal, P., Grandperrin, R., 1994. Modelling the distribution of alfonsino, Beryx splendens, over the seamounts of New Caledonia. Fish. Bull. 92, 748-759.

Marchal, P., Nielsen, J.R., Hovgård, H., Lassen, H., 2001a. Time changes in fishing power in Baltic Sea cod fisheries. ICES J. Mar. Sci. 58, 298-310.

Marchal, P., Ulrich, C., Andersen, J., Pastoors, M., Poos, J.-.J., de Wilde, J.-W., Korsbrekke, K., Casey, J., O'Brien, C., Rackham, B., Pascoe, S., 2001b. On the applicability of biological and economic indicaters to improve the understanding of the relationship between fishing effort and mortality. Examples from the flat- and roundfish fisheries of the North Sea. EU study 98/027.

Maury, O., Gascuel, D., 1999. SHADYS ('simulateur halieutique de dynamiques spatiales'), a GIS based numerical model of fisheries. Example application: the study of a marine protected area. Aquat. Living Resour. 12, 77-88.

Megrey, B.A., 1989. Review and comparison of age-structured stock assessment models from theoretical and applied points of view. Am. Fish. Soc. Symp. 6, 8-48.

Mendelssohn, R., Cury, P., 1989. Temporal and spatial dynamics of a coastal pelagic species, Sardinella maderensis off the Ivory Coast. Can. J. Fish. Aquat. Sci. 46, 1686-1697.

Millischer, L., Gascuel, D., Biseau, A., 1999. Estimation of the overall fishing power: A study of the dynamics and fishing strategies of Brittany's industrial fleets. Aquat. Living Resour. 12, 89-103.

Mohn, R., 1999. The retrospective problem in sequential population analysis: An investigation using cod fishery and simulated data. ICES J. Mar. Sci. 56, 473-488.

Paloheimo, J.E., 1980. Estimation of mortality rates in fish populations. Trans Am. Fish. Soc. 109, 378-386.

Pascoe, S., Robinson, C., 1996. Measuring changes in technical efficiency over time using catch and stock information. Fish. Res. 28, 305-319.

Pascoe, S., Andersen, J., de Wilde, J.W., 2001. The impact of management regulation on the technical efficiency of vessels in the Dutch beam trawl fleet. Eur. Rev. Agr. Econ. 28, 187-206.

Pastoors, M.A., Rijnsdorp, A.D., Van Beek, F.A., 2000. Effects of a partially closed area in the North Sea ('plaice box') on stock development of plaice. ICES J. Mar. Sci. 57, 1014-1022.

Pope, J.G., Shepherd, J.G., 1985. A comparison of the performance of various methods for tuning VPAs using effort data. J. Cons. Int. Explor. Mer 42, 129-151.

Rijnsdorp, A.D., van Mourik Broekman, P.L., Visser, E.G., 2000. Competitive interactions among beam trawlers exploiting local patches of flatfish in the North Sea. ICES J. Mar. Sci. 57, 894-902.

Robson, D.S., 1966. Estimation of the relative fishing power of individual ships. ICNAF Res. Bull. 3, 5-14.

Salz, P., 1996. ITQs in the Netherlands: Twenty years of experience. ICES CM1996.

Shepherd, J.G., 1999. Extended survivors analysis: an improved method for the analysis of catch-at-age data and abundance indices. ICES J. Mar. Sci. 56, 584-591.

Swain, D.P., Nielsen, G.A., Sinclair, A.F., Chouinard, G.A., 1994. Changes in catchability of Atlantic cod (Gadus morhua) to an otter-trawl fishery and research survey in the southern Gulf of St Lawrence. ICES J. Mar. Sci. 51, 493-504. 